\title{
Peripheral blood lymphocyte phenotype and function in multiple sclerosis
}

\author{
P J HUGHES, D A S COMPSTON
}

From the Section of Neurology, University of Wales College of Medicine, Cardiff, UK

SUMMARY $T$ suppressor cell function and phenotype are abnormal in patients with multiple sclerosis, especially during the chronic progressive phase but the sub-populations defined by mitogen stimulation and serological methods may not be identical. In this study, involving 45 patients with multiple sclerosis and 33 controls, there was no correlation between $T$ suppressor function and CD8 cell phenotype in patients with multiple sclerosis or in controls. These phenotypic and functional studies cannot therefore be used interchangeably in the assessment of patients with multiple sclerosis since they provide different information about lymphocyte subpopulations.

Peripheral blood mononuclear (PBM) cell responses to Concanavalin A (Con A) and pokeweed mitogen (PWM) are abnormal in patients with multiple sclerosis; Con A preferentially stimulates $T$ suppressor (Ts) cells whereas PWM is a T cell dependent polyclonal B cell activator. IgG synthesis by unstimulated peripheral blood B lymphocytes is increased in multiple sclerosis patients, especially during relapse and this response is enhanced by PWM stimulation. $^{12}$ These observations have been extended by carrying out sequential assays in which the effect of Con A induced Ts cells on autologous Con A stimulation or PWM induced IgG secretion has been studied. The results are consistent with the interpretation that Ts cell function is impaired in multiple sclerosis patients especially during the chronic progressive phase; $;^{3-8}$ however, co-culture of autologous and allogeneic $B$ and $T$ cells from healthy controls and multiple sclerosis patients suggests that abnormal B cell responses exist in patients with multiple sclerosis which are independent of this putative Ts cell defect. ${ }^{910}$ Phenotypic studies provide additional evidence for a defect in Ts cells in chronic progressive multiple sclerosis. ${ }^{11-16}$ Before replacing time consuming and expensive Con A-PWM assays by $T$ cell enumeration using fluorescent labelled monoclonal antibodies, as a method for investigating Ts cells in patients with multiple sclerosis, it is necessary first to demonstrate whether or not the subpopulations defined by these two methods are

Address for reprint requests: Professor D A S Compston, Department of Neurology, University of Wales College of Medicine, Heath Park, Cardiff CF4 4XN, UK.

Received 30 December 1987.

Accepted 11 April 1988. identical. In this study, PBM responses to Con $\mathrm{A}$ and PWM have been evaluated in 45 patients with multiple sclerosis and 33 unaffected controls; phenotypic and functional results were compared in aliquots of the same sample from 55/78 participants.

\section{Methods}

Preparation of peripheral blood mononuclear cells

PBMs were isolated from $60 \mathrm{ml}$ venous blood, anticoagulated with calcium heparin, on a Ficoll-Hypaque density gradient in sterile $50 \mathrm{ml}$ Falcon tubes by centrifugation at $1000 \mathrm{~g}$ for 35 minutes. PBMs were washed twice in incomplete medium (IM : RPMI 1640, Flow UK; to which $60 \mathrm{mg} / 1$ gentamicin, Roussel, had been added), assessed for cell viability and resuspended in complete medium (CM: $500 \mathrm{ml}$ RPMI 1640 with $10 \mathrm{ml}$ of $100 \mathrm{mM}$ sodium pyruvate, and $10 \mathrm{ml}$ of $200 \mathrm{mM}$ L-glutamine, supplemented with $10 \%$ foetal calf serum, heat inactivated, all Flow, and $30 \mathrm{mg}$ of gentamicin).

\section{Two-stage PBM cultures}

PBMs $\left(5 \times 10^{6}\right)$ in $2 \mathrm{ml} \mathrm{CM}$ were incubated with Con $A$ $(10 \mu \mathrm{g} / \mathrm{ml})$ or $\mathrm{CM}$ in Falcon culture tubes for 48 hours, washed with $0.3 \mathrm{M}$ methyl $\alpha$-D-mannopyranoside (Sigma, $5.68 \mathrm{~g}$ methyl $\alpha$-D-mannopyranoside in $100 \mathrm{ml}$ of IM) to inactive Con $A$, and resuspended in $C M$ at a concentration of $5 \times 10^{6} \mathrm{ml}$. Cell viability was assessed at this stage. $5 \times 10^{5}$ Con A stimulated, and $5 \times 10^{5}$ unstimulated cells were recultured with PWM $(5 \mu \mathrm{l} / \mathrm{ml})$ and made up to a final volume of $1 \mathrm{ml}$ with $\mathrm{CM}$ in each tube. Triplicate cultures containing $1 \times 10^{6}$ cells were incubated for ten days. The cells were then separated by centrifugation at $1000 \mathrm{~g}$ for 10 minutes and the supernatants stored at $-70^{\circ} \mathrm{C}$ for later estimation of IgG concentration by enzyme linked immunosorbent assay (ELISA).

In order to compare Con A-PWM stimulated IgG synthesis with spontaneous and PWM responses, control cul- 
tures were established in which $5 \times 10^{5} \mathrm{PBMs}$, cultured without mitogen for 48 hours were recultured with and without addition of PWM $(5 \mu \mathrm{l} / \mathrm{ml})$, made up to a final volume of $1 \mathrm{ml}$ in culture tubes.

These culture systems assess the interaction of Ts and B lymphocytes. The contribution of B cells to spontaneous IgG secretion is demonstrated by PWM stimulation and Ts activity indicated by sequential Con A-PWM incubation; decreased inducible Ts cell activity and B cell overactivity will each result in increased IgG synthesis during the second stage stimulation with PWM.

\section{ELISA}

Supernatant $(200 \mu \mathrm{l})$ containing IgG was thawed, added to ELISA plates coated with goat antihuman IgG and incubated with goat antihuman IgG F (ab') 2 fragment alkaline phosphatase conjugate (Sigma) for 2 hours at room temperature, followed by $\mathrm{p}$ nitro phenyl phosphate disodium in substrate buffer; the reaction was stopped after approximately 10 minutes with $3 \mathrm{M}$. NaOH and absorbence read. An IgG standard curve was used to calculate IgG concentration in test samples using dilutions between $1: 2$ and $1: 20$.

\section{Identification of $C D 8$ positive cells}

$1 \times 10^{6}$ PBMs, isolated from samples taken between 7.30 and $10 \mathrm{am}$, were incubated with $50 \mu \mathrm{l}$ of OKT8 monoclonal antibody diluted $1: 10$ or phosphate buffered saline (PBS) at room temperature for 6 minutes. Cells were resuspended in medium with $50 \mu \mathrm{l}$ of fluorescein isothiocyanate conjugated (FITC) goat anti-mouse immunoglobulin, incubated at room temperature for a further 6 minutes, resuspended in PBS with $4 \%$ paraformaldehyde and counted within 24 hours by flow cytometry using a fluorescein activated cell sorter (FACS III). Cells were detected and counted at $488 \mathrm{~nm}$ by forward scatter and any fluorescence detected longer than $520 \mathrm{~nm}$ was recorded.

\section{Statistics}

IgG synthesis in two-stage assays was calculated from triplicate samples, following subtraction of background absorbence, using standard curves and expressed in $\mathrm{ng} / \mathrm{ml}$ as a mean and standard deviation. Clinical correlations were masked with respect to the laboratory results. Differences between IgG synthesis and OKT8 cell percentages in individuals from each group were compared by Student's unpaired $t$ test; $p$ values were not corrected for multiple comparisons. Individual results were used to derive the coefficient of correlation between functional and phenotypic results.

\section{Patients}

Con A-PWM stimulated IgG synthesis was investigated on one occasion in 45 patients with multiple sclerosis. Twenty nine had chronic progressive disease and were untreated. Sixteen were participating in a double masked controlled trial of azathioprine $(2 \mathrm{mg} / \mathrm{kg})$; at the time of sampling four were recovering from a recent relapse (two azathioprine and two placebo treated) whereas symptoms were stable or slowly progressive in 12 (six azathioprine and six placebo treated). Ten patients with other neurological diseases (cerebral tumour, Parkinson's disease or peripheral nerve lesions) and 23 healthy controls (six siblings and six cohabitant relatives of seven multiple sclerosis patients, and 10 unrelated individuals) were also investigated.

CD8 cells were enumerated in aliquots of the same peripheral blood sample in 23/45 multiple sclerosis patients and $32 / 33$ healthy or other neurological disease controls.

\section{Results}

\section{Two stage Concanavalin A-pokeweed mitogen stimulated IgG synthesis}

Spontaneous IgG synthesis was increased in multiple sclerosis patients $(220, \mathrm{SD} 361 \mathrm{ng} / \mathrm{ml})$ compared with controls (76, SD $82 \mathrm{ng} / \mathrm{ml}$ ). After PWM stimulation, IgG synthesis increased in patients $(4186, \mathrm{SD}$ $5344 \mathrm{ng} / \mathrm{ml}$ ) and controls (1324, SD $1818 \mathrm{ng} / \mathrm{ml})$. These differences were statistically significant ( $\mathrm{p}<0.02$ and $<0.01$ respectively: table 1$)$. IgG synthesis after sequential two stage Con A-PWM incubation was reduced, as expected, compared with PWM stimulation alone (although the results cannot directly be compared since different cell numbers were used under these two culture conditions) in multiple sclerosis patients $(1525, \mathrm{SD} 1969 \mathrm{ng} / \mathrm{ml})$ and controls (990, SD $1193 \mathrm{ng} / \mathrm{ml})$ but the difference was not significant $(0 \cdot 5:>p>0.01)$.

Results have also been analysed depending on treatment or disease activity in affected individuals and within the separate categories of controls. There was increased spontaneous IgG synthesis in 29 patients with chronic progressive multiple sclerosis (210, SD $371 \mathrm{ng} / \mathrm{ml}$ ) compared with 10 unrelated normal $(50$, SD $60 \mathrm{ng} / \mathrm{ml}: \mathrm{p}<0.05)$ and 10 other neurological disease controls $(75, \mathrm{SD} 31 \mathrm{ng} / \mathrm{ml}: \mathrm{p}=\mathrm{NS}$ : table 2$)$.

Table 1 IgG synthesis in two stage Con $A-P W M$ cultures

\begin{tabular}{|c|c|c|c|c|}
\hline & $\begin{array}{l}\text { Spontaneous } \\
\text { IgG synthesis } \\
(\mathrm{ng} / \mathrm{ml}, \mathrm{SD})\end{array}$ & $\begin{array}{l}\text { PWM stimulated } \\
\text { IgG synthesis } \\
(\mathrm{ng} / \mathrm{ml}, S D)\end{array}$ & $\begin{array}{l}\text { Con } A-P W M \text { stimulated } \\
\text { IgG synthesis } \\
(\mathrm{ng} / \mathrm{ml}, S D)\end{array}$ & $T 8+(\%)$ \\
\hline $\begin{array}{l}\text { All multiple sclerosis patients } \\
\text { number }\end{array}$ & $\begin{array}{l}220,361 \\
45\end{array}$ & $\begin{array}{l}4186,5344 \\
45\end{array}$ & $\begin{array}{l}1525,1969 \\
45\end{array}$ & $\begin{array}{l}17,6 \\
23\end{array}$ \\
\hline $\begin{array}{l}\text { All controls } \\
\text { number }\end{array}$ & $\begin{array}{l}76,82 \\
33\end{array}$ & $\begin{array}{l}1324,1818 \\
33\end{array}$ & $\begin{array}{l}990,1193 \\
33\end{array}$ & 21,7 \\
\hline$t$ & $2 \cdot 586$ & $3 \cdot 386$ & 1.487 & $2 \cdot 273$ \\
\hline $\mathrm{p}$ & $<0.02$ & $<0.01$ & $0.5>p>0.1$ & $<0.05$ \\
\hline
\end{tabular}


Table 2 IgG synthesis in two stage Con A-PWM stimulated cultures

\begin{tabular}{|c|c|c|c|c|}
\hline & $\begin{array}{l}\text { Spontaneous } \\
\text { IgG synthesis } \\
(\text { Mean, } S D ; n g / m l)\end{array}$ & $\begin{array}{l}\text { PWM stimulated } \\
\text { IgG synthesis } \\
(M e a n, S D ; n g / m l)\end{array}$ & $\begin{array}{l}\text { Con } A-P W M \text { stimulated } \\
\text { IgG synthesis } \\
(M e a n, S D ; n g / m l)\end{array}$ & $T 8+$ cells $(\%)$ \\
\hline $\begin{array}{l}\text { Multiple sclerosis: } \\
\text { Chronic progressive }(n=29) \\
\text { Neurological controls }(n=10) \\
\text { Normal controls }(n=10)\end{array}$ & $\begin{array}{r}210,371 \\
75,31 \\
50,60\end{array}$ & $\begin{array}{l}4953,5940 \\
1505,1746 \\
1500,2502\end{array}$ & $\begin{array}{c}1793,2279 \\
1184,1304 \\
649,823\end{array}$ & $\begin{array}{l}\overline{21}, 8 \\
24,7\end{array}$ \\
\hline $\begin{array}{l}\text { Family studies: } \\
\text { Patients }(n=7)^{*} \\
\text { Cohabitant relatives }(n=7) \\
\text { Non-cohabitant relatives }(n=6)\end{array}$ & $\begin{array}{l}59,48 \\
55,42 \\
146,159\end{array}$ & $\begin{array}{l}2454,2714 \\
528,429 \\
1657,1744\end{array}$ & $\begin{array}{c}1810,2293 \\
851,855 \\
1395,1850\end{array}$ & $\begin{array}{l}13,6 \\
15,4 \\
22,6\end{array}$ \\
\hline
\end{tabular}

*Also included in all chronic progressive multiple sclerosis patients.

Statistical details are available in text.

PWM stimulated IgG synthesis was also significantly higher in these multiple sclerosis patients (4953, SD $5940 \mathrm{ng} / \mathrm{ml})$ than normal $(1500$, SD 2502: $\mathrm{p}<0.02)$ and other neurological disease controls (1505, SD $1746 \mathrm{ng} / \mathrm{ml}: \mathrm{p}<0.01)$. As expected the addition of Con A incubated autologous cells inhibited PWM stimulated IgG synthesis; there was a significant difference in IgG production between multiple sclerosis patients $(1793, \mathrm{SD} 2279 \mathrm{ng} / \mathrm{ml})$ and normal $(649$, SD $823 \mathrm{ng} / \mathrm{ml}: \mathrm{p}<0.05)$ but not other neurological disease controls (1184, SD 1304: $p$ NS) after sequential Con A-PWM stimulation.

Although spontaneous IgG secretion was not increased in the seven patients with chronic progressive multiple sclerosis $(59$, SD $48 \mathrm{ng} / \mathrm{ml})$ in whom comparisons were made with cohabitant $(55$, SD $42 \mathrm{ng} / \mathrm{ml}$ ) or non-cohabitant relatives $(146$, SD $159 \mathrm{ng} / \mathrm{ml}$ ), these patients showed increased IgG synthesis in response to PWM stimulation (2454, SD $2714 \mathrm{ng} / \mathrm{ml}$ ) compared with each group of relatives (528, SD 429 and 1657, SD $1744 \mathrm{ng} / \mathrm{ml}$ respectively) but these differences were not statistically significant.

Table 3 IgG synthesis in Con A-PWM stimulated cultures in azathioprine treated patients with multiple sclerosis

\begin{tabular}{|c|c|c|c|}
\hline $\begin{array}{l}\text { Spontaneous } \\
\text { IgG synthesis }\end{array}$ & $\begin{array}{l}\text { Azathioprine } \\
(\text { Mean, SD;ng/ml) }\end{array}$ & $\begin{array}{l}\text { Placebo } \\
\text { (Mean, SD; } \mathrm{ng} / \mathrm{ml})\end{array}$ & $\begin{array}{l}\text { All } \\
\text { (Mean, SD; ng/ml) }\end{array}$ \\
\hline $\begin{array}{l}\text { Multiple sclerosis: } \\
\text { Relapse } \\
\text { Multiple sclerosis: } \\
\text { Stable } \\
\text { Multiple sclerosis: } \\
\text { All }\end{array}$ & $\begin{array}{c}140,99 \\
(n=2) \\
188,291 \\
(n=6) \\
176,250 \\
(n=8)\end{array}$ & $\begin{array}{c}205,282 \\
(n=2) \\
330,500 \\
(n=6) \\
299,439 \\
(n=8)\end{array}$ & $\begin{array}{c}173,177 \\
(n=4) \\
259,397 \\
(n=12) \\
-\end{array}$ \\
\hline
\end{tabular}

PWM Stimulated IgG synthesis

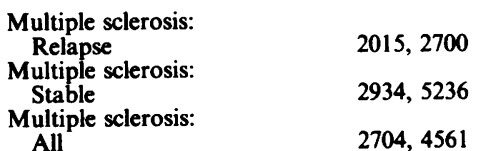

Multiple sclerosis:

Multiple sclerosis:

All

2704,4561

2832, 2358

2424,2123

2907,3725

2920,4332

2889,3272
Con A-PWM Stimulated IgG synthesis

Multiple sclerosis: Relapse

Stable

Multiple sclerosis: All

1435, 1746

946, 1506

1068,1451

\section{OKT8 Cells}

Multiple sclerosis:

Relapse

Multiple sclerosis: Stable

Multiple sclerosis:

All

\section{$13.5,4.9$}

$18 \cdot 2,5 \cdot 1$

$17 \cdot 0,5 \cdot 2$
1755, 7

1595,1025

761,787

853,1149

1009,809

(percentages)

$15 \cdot 0,1 \cdot 4$

$14 \cdot 2,3 \cdot 1$

$21 \cdot 3,6 \cdot 0$

$19 \cdot 7,5 \cdot 6$

Statistical details are available in text. 


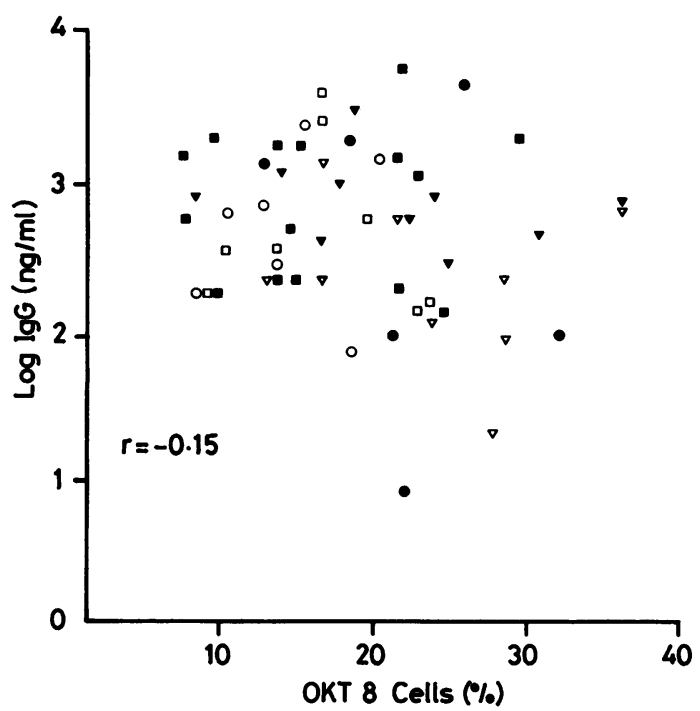

Fig Lack of inverse correlation between OKT8 positive (CD8) cell percentages and log transformed IgG synthesis in sequential concanavalin A-pokeweed mitogen stimulated cultures of peripheral blood mononuclear cells in 15 untreated patients with multiple sclerosis ( $\square$ ), 8 affected individuals receiving azathioprine $2.5 \mathrm{mg} / \mathrm{kg}$ ( $\square$ ), 7 unaffected cohabitant relatives (O), 6 unaffected non-cohabitant relatives (O), 9 normal controls $(\nabla)$, 10 patients with other neurological diseases $(\nabla)$.

In two stage Con A-PWM cultures, patients showed increased IgG synthesis $(1810$, SD $2293 \mathrm{ng} / \mathrm{ml})$ compared with cohabitant $(851$, SD $855 \mathrm{ng} / \mathrm{ml})$ and noncohabitant relatives $(1395$, SD $1850 \mathrm{ng} / \mathrm{ml}$ : $\mathrm{pNS}$ for each comparison).

Spontaneous IgG synthesis was increased in eight placebo treated cases $(299$, SD $439 \mathrm{ng} / \mathrm{ml})$ compared with eight patients who had taken azathioprine $(2.5 \mathrm{mg} / \mathrm{kg})$ for at least 2 years $(176$, SD $250 \mathrm{ng} / \mathrm{ml})$ but this difference was not statistically significant; in each group there was a trend towards higher IgG synthesis in clinically stable cases compared with those in relapse (table 3). After PWM stimulation there were no differences in IgG synthesis between placebo (2889, SD $3272 \mathrm{ng} / \mathrm{ml}$ ) and azathioprine treated $(2704$, SD $4561 \mathrm{ng} / \mathrm{ml}$ ) patients or between clinically stable $(2920$, SD $4332 \mathrm{ng} / \mathrm{ml})$ and active cases $(2424$, SD $2123 \mathrm{ng} / \mathrm{ml}$ ). The addition of Con A incubated autologous cells caused greater inhibition of PWM stimulated IgG synthesis in stable cases (853, SD $1149 \mathrm{ng} / \mathrm{ml})$ than patients in relapse $(1595$, SD $1025 \mathrm{ng} / \mathrm{ml}$ ); this difference was statistically significant in placebo treated patients $(761$, SD 787 vs 1755 , SD 7: $p<0.05)$ and a similar trend was observed in the azathioprine treated group (946, SD 1506 vs 1435 , SD $1746 \mathrm{ng} / \mathrm{ml}: \mathrm{p}=\mathrm{NS}$ ) but no overall effect of azathioprine was demonstrated under these culture conditions.

\section{CD8 positive phenotypes}

Mean CD8 positive cell percentage was lower in 23 multiple sclerosis patients $(17$, SD $6 \%$ ) than 32 controls $(21$, SD 7\%: $p<0.05$ : table 1). There was no correlation between $\mathrm{T}$ lymphocyte function in Con A-PWM 2 stage cultures and CD8 positive cell phenotype in patients or controls $(R=-0 \cdot 15$ : fig).

Mean CD8 positive cell percentages were significantly lower in seven untreated patients with chronic progressive multiple sclerosis $(14$, SD $6 \%)$ than nine normal $(24$, SD $7 \%: p<0.01)$ or 10 neurological disease controls $(22$, SD $8 \%: p<0.05)$, and six non-cohabiting siblings (22, SD 6\%: $p<0.05$ : table 2). Mean CD8 positive cell percentages were also reduced in seven cohabiting family members (15, SD $4 \%)$ compared with non-cohabitants $(p<0.05)$ and unrelated normal $(p<0.01)$ or other neurological disease controls $(p<0.05)$. These results reproduce the findings of a previous study involving the same participants. ${ }^{17}$

Overall there was no difference in mean CD8 positive cell percentages in eight azathioprine (17, SD 5\%) compared with eight placebo treated patients $(20, S D$ $6 \%$ ). Mean CD8 positive cell percentages were lower in four patients during relapse $(14$, SD $3 \%)$ than stable cases $(20$, SD 6\%: $\mathrm{p}<0.05)$ an effect which was seen in placebo ( 21 , SD $6 \%$ vs 15, SD $1 \%$ ) and azathioprine treated patients $(18$, SD $5 \%$ vs 13 , SD $5 \%$ : table 3).

\section{Discussion}

In this study we found no overall correlation between CD8 cell phenotype (using the OKT8 marker) and Con A-PWM induced IgG synthesis in patients with multiple sclerosis or controls. The lack of even a noncausal relationship is at first surprising, since each method gave abnormal results in individuals with multiple sclerosis. But the outcome of cultures, containing an heterogenous population of cells, stimulated with one or more plant mitogens for up to 12 days is likely to depend on more than just the initial number of CD8 cells in the test sample. There was a statistically significant difference in IgG synthesis after PWM but not sequential Con A-PWM stimulation between groups consistent with the interpretation that increased spontaneous IgG synthesis in patients with multiple sclerosis, which reflects the balance of lymphocyte interaction in vivo, is more likely to depend on B cell overactivity than impaired Ts function.

Abnormalities of PWM stimulated IgG secretion and number of OKT8 positive cells or T cells bearing 
receptors for IgG immune complexes ( $\mathrm{Tg}$ ), were originally correlated in groups of patients with multiple sclerosis recovering from relapse; ${ }^{12}$ later the reduction in OKT8 cells during relapse was associated with impaired control of EBV specific T cell mediated cytotoxicity. ${ }^{18}$ However, a number of other detailed studies in multiple sclerosis patients have since shown no correlation between phenotypic and functional tests. Tjernlund et $a^{8}{ }^{8}$ using a two stage Con A-mixed lymphocyte reactivity culture, demonstrated an increase in OKT4/8 ratio and spontaneous or PWM stimulated IgG synthesis with reduced stimulation indices in patients with chronic progressive multiple sclerosis but not cases in remission; the results of neither functional test correlated with phenotype in individual patients. Oger et al $^{19}$ demonstrated comparable Leu 2a/OKT8 cell phenotypes and two-stage Con A-Con A proliferative responses in normal individuals whereas in multiple sclerosis patients functional abnormalities correlated only with the number of Leu 2a positive cells. The authors considered that the population determining suppressor function could best be identified by double-labelling using OKT8 and Leu 7 monoclonal antibodies. In a series of papers, Antel and colleagues 2021 concluded that the Ts defect in multiple sclerosis patients is largely accounted for by a combined numerical and functional abnormality of the CD8 population, whereas T8 cell cytotoxic function is normal in an assay involving pooled allogeneic responder cells. Other cell types, including CD4 and all E rosette positive cells, contribute to suppressor function but the deficit in multiple sclerosis patients may selectively involve the CD8 population. Recently, a reduction in peripheral blood suppressor inducer cell phenotype, identified by dual labelling with OKT4 and 2H4 monoclonal antibodies, has been correlated with a two stage assay in which Ts cells were first expanded in a mixed autologous lymphocyte reaction, and then incubated with PWM stimulated mononuclear cells, followed by estimation of supernatant IgG concentration. ${ }^{22}$

Patients involved in a controlled treatment trial of azathioprine were investigated in order to extend the comparison between $T$ cell phenotype and function and to assess the role of antigen non-specific suppressor assays in the assessment of immunological treatment. In patients with active multiple sclerosis, azathioprine has been shown to decrease Ts cell numbers $^{23}$ and return abnormal Con $A$ mitogenic responses and suppressor activity in $\operatorname{Con} A-\operatorname{Con} A$ assays to the normal values seen in untreated stable cases. $^{24}$ We have demonstrated differences in two stage assays in untreated patients, which varied with disease activity, but these were uninfluenced by azathioprine given at a dose of $2.5 \mathrm{mg} / \mathrm{kg}$; the variables on which disease activity depends remained a more potent influence on mitogen responsiveness. However, it remains to be shown whether improving Ts function or CD8 cell number is beneficial for multiple sclerosis patients and despite theoretical considerations there are sufficient gaps in understanding the pathogenesis of the disease to make the clinical consequences of any immunological treatment unpredictable. Better understanding of the in vitro effect of each drug on immune abnormalities in multiple sclerosis may accelerate progress in identifying the most promising candidates for future clinical trials.

The results of this investigation of peripheral blood $T$ cells in patients with multiple sclerosis indicate that phenotypic and functional tests provide different information about cellular interactions and so cannot be used interchangeably in the assessment of peripheral blood lymphocytes in patients with multiple sclerosis.

\section{References}

1 Goust JM, Hoffman PM, Pyrjma J, Hogan EL, Fudenberg HH. Defective immunoregulation in multiple sclerosis. Ann Neurol 1980;8:526-33.

2 Antel JP, Rosenkoetter M, Reder A, Oger JJ-F, Arnason BGW. Multiple sclerosis: relation to in vitro IgG secretion to $\mathrm{T}$ suppressor cell number and function. Neurology 1984;34:1155-60.

3 Antel JP, Arnason BGW, Medof ME. Suppressor cell function in multiple sclerosis. Correlation with clinical disease activity. Ann Neurol 1979;5:338-42.

4 Gonzalez RL, Dau PC, Spitler LE. Altered regulation of mitogen responsiveness by suppressor cells in multiple sclerosis. Clin Exp Immunol 1979;36:78-84.

5 Wallen WC, Houff SA, Iivanainen M, Calebrese VP, Devrier GH. Suppressor cell activity in multiple sclerosis. Neurology 1981;31:668-74.

6 Sheremata WA, Rzepiela AJ, Sazant A, Berger J. Confirmation of Con-A inducible suppressor cell function in multiple sclerosis. Neurology 1982;32:A145S.

7 Haahr S, Muller-Larsen A, Pedersen E. Immunological parameters in multiple sclerosis patients with special reference to the herpes virus group. Clin Exp Immunol 1983;51:197-206.

8 Tjernlund U, Cesaro P, Tournier E, Degos J-D, Bach J-F, Bach $M-A$. $T$ cell subsets in multiple sclerosis: a comparative study between cell surface antigens and function. Clin Immunol Immunopathol 1984;32:185-97.

9 Kelley RF, Ellison GW, Myers LW, Goymerac V, Larrick SE, Kelley CC. Abnormal regulation of in vitro IgG production in multiple sclerosis. Ann Neurol 1981;9:267-72.

10 Goust J-M, Hogan EL, Arnaud P. Abnormal regulation of IgG production in multiple sclerosis. Neurology 1982;32:228-34.

11 Reinherz EL, Weiner HL, Hauser SL, Cohen JA, Distaso JA, Schlossman SF. Loss of suppressor $\mathrm{T}$ cells in active multiple sclerosis. N Engl J Med 1980;303:124-9.

12 Huddlestone JR, Oldstone MBA. Suppressor T cells are activated in vivo in patients with multiple sclerosis coinciding with remission from acute attack. J Immunol 1982;129:915-7.

13 Scott CF, Spitler LE. Lymphocytotoxic antibody in multiple sclerosis: activity against $T$ cell subsets and correlation with disease activity. Clin Exp Immunol 1983;53:133-9.

14 Compston DAS. Lymphocyte subpopulations in patients with multiple sclerosis. J Neurol Neurosurg Psychiatry 1983;46: 105-14.

15 Hauser SL, Reinherz EL, Hoban CJ, Schlossman SF, Weiner HL. Immunoregulatory $\mathrm{T}$-cells and lymphocytotoxic antibodies in 
active multiple sclerosis: weekly analysis over a six month period. Ann Neurol 1983;13:418-25.

16 Bach M-A, Martin C, Cesaro P, Eizenbaum JF, Degos JD. T cell subsets in multiple sclerosis-a longitudinal study of exacerbating remitting cases. $J$ Neuroimmunol 1985;7:331-43.

17 Hughes PJ, Kirk PF, Compston DAS. Suppressor T cells in family members of patients with multiple sclerosis. Brain 1986;109:969-85.

18 Craig JC, Hawkins SA, Swallow MW, et al. Subsets of T lymphocytes in relation to $\mathrm{T}$ lymphocyte function in multiple sclerosis. Clin Exp Immunol 1985;61:548-55.

19 Oger J, Kastrukoff L, O'Gorman M, Paty DW. Progressive multiple sclerosis: abnormal immune functions in vitro and aberrent correlation with enumeration of lymphocyte subpopulations. J Neuroimmunol 1986;12:37-48.

20 Antel JP, Bania MB, Reder A, Cashman N. Activated suppressor cell dysfunction in progressive multiple sclerosis. $J$ Immunol 1986;137:137-41.

21 Antel JP, Nicholas MK, Bania MB, Reder AT, Arnason BGW, Joseph L. Comparison of $\mathrm{T} 8+$ cell mediated suppressor and cytotoxic function in multiple sclerosis. $J$ Neuroimmunol 1986;12:215-24.

22 Chofflon MM, Weiner HL, Hafler DA. Loss of functional suppression is linked to decreases in circulating suppressor inducer $(C D 4+2 \mathrm{H} 4+)$ T cells in multiple sclerosis. Neurology 1987;37 (suppl 1.):294.

23 Trotter JL, Rodey GE, Gebel HM. Azathioprine decreases suppressor T cells in patients with multiple sclerosis. $N$ Engl J Med 1982;306:365-6.

24 Oger JJ-F, Antel JP, Kuo HH, Arnason BGW. Influence of azathioprine (Imuran) on in vitro immune function in multiple sclerosis. Ann Neurol 1982;11:177-81.

From the Archives of Surgery ${ }^{1}$ Sir Jonathan Hutchinson's (1829-1913) modern description of symmetrical temporal arteritis.

"The subject ... was an old man ... the father of a well-remembered beadle at the London Hospital College 30 years ago ... I was asked to see him because he had red 'streaks on his head' which were painful and prevented his wearing his hat. The 'red streaks' proved ... to be his temporal arteries which ... were ... inflamed and swollen. Pulsation could be feebly detected in the affected vessel, but it finally ceased; the redness then subsided, and the vessels were left impervious cords. The old gentleman lived, I believe, several years after this without any other manifestion of arterial disease."

RT ROSS, MD

\section{Reference}

1 Hutchinson J. Diseases of the Arteries. Arch Surg 1890;1:323-33. 